\title{
EVOLUTION OF GEOSPHERE AT THE SITE IN THE NIZHNEKANSKIY MASSIF PROPOSED FOR DEEP GEOLOGICAL REPOSITORY CONSTRUCTION
}

\author{
Kochkin B. T. ${ }^{1,2}$, Bogatov S. A. ${ }^{2}$, Barinov A. S. ${ }^{2}$, Saveleva E. A. ${ }^{2}$, Utkin S. S. ${ }^{2}$ \\ ${ }^{1}$ Institute of Geology of Ore Deposits, Petrography, Mineralogy, and Geochemistry of the Russian Academy of Sciences, \\ Moscow, Russia \\ ${ }^{2}$ Nuclear Safety Institute of the Russian Academy of Sciences, Moscow, Russia
}

Article received on February 5, 2020

\begin{abstract}
The paper identifies external geological impacts (FEPs) governing the long-term evolution of the disposal facility at the Yeniseyskiy site. It evaluates the current level of knowledge concerning these factors along with focus areas proposed for further investigations involving: studies of tectonic movements, deformation of rocks and seismic monitoring.
\end{abstract}

Keywords: radioactive waste, deep disposal of RW, geosphere evolution, FEPs, geological investigations.

\section{Introduction}

In keeping with Russian regulatory framework and international recommendations, deep disposal safety should be demonstrated based on predictive model calculations covering a time period during which the disposed RW remains potentially hazardous. Thus, according to [1], "radioactive waste disposal system, i. e. a complex of natural geological formations, structures ... and disposed RW, meets safety requirements if, during the entire period associated with the potential hazards presented by the disposed RW, the radiation impact on the population is limited to levels specified in radiation safety standards".

As a natural geological formation, the geosphere is characterized by a combination of factors affecting its evolution (of constant or abrupt occurrence) during the time period associated with the potential hazards presented by the disposed RW, i. e. hundreds of thousands and millions of years.

The article presents the focus areas of research required for an adequate demonstration of the repository evolution, namely of the geospheric part of the disposal system at the Yeniseiskiy site.
Features, events, processes (FEPs) and their classification

Long-term safety demonstration suggests the use of a unified concept describing various factors potentially contributing to the safety of a disposal system: the FEP concept. IAEA recommendations [2] provide the following explanation of these terms. Features are objects, structures or conditions that can potentially affect the reliability of a disposal system. Event is a natural or anthropogenic phenomenon that can significantly affect the reliability of the disposal system and manifests itself during a time interval that is shorter than the forecast period. Process is a natural or human-induced phenomenon that can significantly affect the reliability of a disposal system and is acting during the entire forecast period or its sizable part.

A huge amount of work has been done globally to evaluate the geological disposal safety and to develop FEPs bases. Some were tailored specifically for particular disposal designs or type of bedrock, others are generic. Similar work has been implemented in Russia. Thus, FEPs are considered in IGEM RAS [3-5] and IBRAE RAS [6] publications, in particular, 


\begin{tabular}{|c|c|c|c|}
\hline \multicolumn{4}{|c|}{ 1. EXTERNAL FACTORS } \\
\hline $\begin{array}{l}\text { 1.1 Repository } \\
\text { Issues }\end{array}$ & $\begin{array}{c}1.3 \text { Climatic } \\
\text { Factors }\end{array}$ & $\begin{array}{l}\text { 1.4 Future Human } \\
\text { Actions }\end{array}$ & $\begin{array}{l}\text { 1.5 Other External } \\
\text { Factors }\end{array}$ \\
\hline \multicolumn{4}{|l|}{ DISPOSAL SYSTEM } \\
\hline $\begin{array}{l}\text { 2. WASTE PACKAGE FACTORS } \\
\text { 2.1 Waste Form Characteristics and Properties } \\
\text { 2.2 Waste Packaging Characteristics and Properties } \\
\text { 2.3 Waste Package Processes } \\
\text { 2.4 Contaminant Release (from waste form) } \\
\text { 2.5 Contaminant Transport (waste package) }\end{array}$ & $\begin{array}{l}\text { 3. EBS } \\
\text { 3.1 EBS Characteristics } \\
\text { and Properties } \\
\text { 3.2 Degradation } \\
\text { Processes } \\
\text { 3.3 Migradion } \\
\text { Processes }\end{array}$ & $\begin{array}{l}\text { 4. GEOSPHERE FACTORS } \\
\text { 4.1 Characteristics } \\
\text { and Properties } \\
\text { 4.2 Evolution } \\
\text { Processes } \\
\text { 4.3 Migration } \\
\text { Processes }\end{array}$ & $\begin{array}{l}\text { 5. BIOSPHERE FACTORS } \\
\text { 5.1 Surface Environment } \\
\text { 5.2 Human Behaviour } \\
\text { 5.3 Contaminant } \\
\text { Transport } \\
\text { (biosphere) } \\
\text { 5.4 Exposure Factors }\end{array}$ \\
\hline
\end{tabular}

Figure 1. Layout of NEA OECD's FEPs catalogue

those directly associated with the proposed deep disposal facility to be built at the Yeniseiskiy site.

Starting from 1993, OECD NEA's Radioactive Waste Management Commission has been developing a generic international FEPs catalog. The latest (third) edition of this catalog was published in 2019 and includes 268 items [7]. This catalog is currently considered as the most complete one enabling to develop FEPs lists tailored for any specific designs (Figure 1). It was developed based on factors potentially affecting repository subsystems. The classification takes into account all possible interactions, direct links and feedback allowing to determine the application scope of certain FEPs given specific disposal designs and compare them with the FEPs from the generic catalog. The catalog includes 5 groups of factors (Figure 1). Geological FEPs are directly indicated under the group of External Factors (subsection 1.2) and also constitute to a group of Geosphere Factors (column 4). Geosphere Conditions are, in turn, influenced by Climatic Factors (subsection 1.3) and Future Human Actions (subsection 1.4). Internal factors (groups 2 and 3) associated with waste matrix (radionuclide composition) or the processes occurring in the repository (inside the engineered safety barrier system, EBS) will produce certain impact on contaminant migration in the geosphere.

FEPs presented in the OECD NEA catalog involve those factors that are necessary to fill up the migration models with specific values, and those that are necessary to describe evolutionary changes of parameters under the migration models. To some extent, such a division corresponds to the provisions of Russian regulatory framework. In particular, a regulation [1] indicates that: "The final ... lists of initiating events taken into account in long-term safety assessments of radioactive waste disposal systems should be compiled and justified in the designs..." and in the Safety Analysis Report (SAR).

Appendix No.4 [1] specifies a list of initiating events that should be considered during the development of scenarios under the long-term safety assessments of deep SRW disposal systems, involving:

1. External impacts of natural and man-induced origin inherent to the repository siting area, including changes in the hydrogeological mode, activation of tectonic processes, changes in the seismic mode. Evaluation of external impacts should involve the consideration of the catastrophic ones, including earthquakes above DLE.

2. Inadvertent human intrusion, including drilling and mining operations, various types of industrial activities.

3. Internal impacts including hazardous processes occurring in the EBS.

The list of external geological FEPs involves those being associated with the geological environment that will basically manifest themselves in the far field of the underground structure. In some cases, they can affect the engineered safety barrier system (Table 1).

\section{Table 1. Geological FEPs contributing to the evolution of the disposal system (according to [7])}

\begin{tabular}{c} 
FEP's ID number and name \\
\hline 1 External factors
\end{tabular}

1.2: Geological factors

1.2.1: Tectonic movement

1.2.2: Orogeny

1.2.3: Deformation (elastic, plastic or brittle)

1.2.4: Seismicity

1.2.5: Magmatic and volcanic activity

1.2.6: Metamorphism

1.2.7: Hydrothermal activity

1.2.8: Regional erosion and sedimentation

1.2.9: Diagenesis

1.2.10: Pedogenesis

1.2.11: Salt dissolution

1.2.12: Hydrological/hydrogeological response to geological changes 1.2.13: Geomorphological response to geological changes

1.2.14: Climatic responses to geological changes 
FEPs identification is considered as the initial task of their evaluation, namely, the compilation of their exhaustive list covering the entire possible range of factors considered as potentially important in terms of assessing the state of a disposal system at a specific site in a long-term perspective. The following step provides for the selection (screening) of the most important FEPs that are individually or collectively responsible for the long-term reliability of a specific DF RW.

During the identification of FEPs that will determine the scenarios of disposal system evolution and being also considered relevant for the Yeniseiskiy site, identified are the external FEPs with a minor probability of their occurrence in the region in the foreseeable future. Thus, already at the stage of regional surveys covering the siting area of the repository within the Yenisei Ridge [8], scenarios of system evolution associated with particularly strong earthquakes, volcanism, hydrothermal activity, denudation of the overlying rock mass and high groundwater inflow rate were practically excluded. Scenarios describing inadvertent human intrusion in search for minerals, terrorist acts, military operations, a meteorite fall, etc., require special consideration not being related to the geological factors.

Further evaluations were mainly focused on those FEPs that would determine the scenarios associated with the evolution of geological setting and governing radionuclide migration through the geosphere (subsection 1.2) according to the OECD NEA classification [7] (see Table 1). Flow driven migration of radionuclides is recognized as a most likely mechanism responsible for radionuclide transfer from the underground structures to the biosphere. It is that this mechanism was considered as a basis for the development of a mathematical model simulating geosphere transport under predictive dose and risk calculations. Uncertainties in the forecasts regarding the evolution of each of the individual geosphere factors will determine different scenario options implemented under such calculations.

The order of FEPs presentation below corresponds to the one of the NEA OECD catalogue [7]. The importance of individual FEPs in terms of their potential impact on safety was estimated based on expert judgments.

\section{External geological factors relevant} for the Yeniseiskiy site (FEP 1.2)

External geological factors are factors associated with long-term processes and events arising from the general geological setting and affecting disposal system performance and safety.
At the current stage, the following factors can be excluded from consideration: Orogeny (1.2.2), Magmatic or volcanic activity (1.2.5), Metamorphism (1.2.6), Hydrothermal activity (1.2.7), i. e. processes that based on general geological knowledge were judged as having minor probability of their occurrence at the Yeniseiskiy site. Also excluded from consideration were the processes not being relevant for crystalline rock medium found in the siting region: Diagenesis (1.2.9), Pedogenesis (1.2.10), Dissolution of salts (1.2.11).

\section{FEP 1.2.1: Tectonic movements}

Movements of lithospheric plates representing the outermost layer of the Earth are driven by convection movement of masses in the underlying mantle. These movements give rise to large-scale processes lasting millions of years, such as continental drift, formation of mountains (orogeny) or rifts and various crustal deformations, including depressions, faults, folds and other geological structures.

Given the scale of the geological regions, processes associated with multidirectional vertical movements of the earth's crust (elevation/subsidence) impact the local hydrodynamics. These changes cause the displacement of recharge and discharge area boundaries, as well as vertical differentiation of the groundwater level along the area (related with FEP 1.2.12). In the regions with recent minor post-platform tectonic activation, including the Yenisei Ridge, the upheaval of elevated areas is accompanied by the subsidence of the conjugated lowlands and depressions due to the differentiated nature of the neighboring block movements (related with FEP 1.2.13).

Vertical movements of the earth's crust are considered as a constantly acting factor. They are intermittent and reversible by their nature; thus, their average rate strongly depends on the averaging period. Data on the rates of vertical movements occurring in the repository siting region are known and have been repeatedly listed in literature [9-11]. Even considering minimal averaging periods (Holocene), these rates did not exceed $1 \mathrm{~mm} /$ year, whereas, considering periods of millions of years, they would amount to $0.08-0.09 \mathrm{~mm}$ /year. The impact produced by vertical differentiation of geological blocks on groundwater migration parameters depends on the actual rate and direction of tectonic movements. An increased discrepancy in the groundwater levels between the recharge and discharge areas will intensify water exchange, which is considered unfavorable in terms of the safety assessment. Such a forecast for the Yeniseiskiy siting region was provided in [12]. Based on it, 
the relevance of vertical block differentiation can be estimated as average.

In addition to vertical movements, horizontal displacements of the neighboring blocks along the existing faults can occur. Their potential occurrence was also identified in the repository siting region. Horizontal displacements can undermine safety due to potential EBS deformations. Relevance of horizontal block differentiations will depend on the actual rate and direction of tectonic movements along the fracture zones inside the waste emplacement block. Topographic maps revealed Itatskiy (Shumikhinskiy) right shift located at a distance of $1 \mathrm{~km}$ north of the intended site and stretching in the northwest direction along the Shumikha river. Displacement of watercourses on both sides of it (up to 800-900 $\mathrm{m}$ over the last 2.5 million years) helped to estimate its rate amounting to 0.4$0.5 \mathrm{~mm}$ /year [13]. Short-term instrumental measurements performed in the repository siting area (2010-2015) identified cyclic displacements of observation points on the both sides of the river Yenisei. The data obtained is believed to be insufficient to demonstrate that this FEP does not impose any risk. Therefore, continuous observations should be arranged for $[14,15]$.

\section{FEP 1.2.3: Rock deformation (elastic, ductile or brittle)}

Tectonic movements in the earth's crust involve various kinds of deformations, mainly occurring along discontinuous disturbances causing no abrupt displacements (the so-called creep) and, accordingly, earthquakes. These active faults particularly suggest that these tectonic processes evolved along these discontinuous structures of the earth's crust in a recent geological past, are still evolving and can evolve in the future. Faults that were formed or manifested themselves at the latest tectonic stage of the earth's crust development (last 26 million years) are referred to as "newest". Displacements along active faults may be caused by ancient fault rejuvenation or the development of some new cracks [16].

The nature of "aseismic" fault activity depends on the stability or reversibility of the displacement direction, the total amplitude of the displacement and fluid permeabilities [17]. Large amplitudes are manifested in the landscape deformations (related with FEP 1.2.13). Due to creep, mechanical deformations along the active faults build up slowly and can potentially cause EBS failure in the future. Aseismic faults, continuously considered as loosen zones of the earth's crust, are characterized with increased hydraulic permeability in comparison with the monolithic bedrocks or healed ancient faults. In the long run, permeable active faults can significantly affect contaminant spread in the environment.

Currently, no research findings suggest that the availability of active faults within the site boundaries or outside can be unambiguously confirmed or ruled out, even though modern movements in the area are recorded instrumentally using satellite geodesy and repeated high-precision leveling $[11,14$, $15]$. Based on geomorphological research data $[8,13$, $18,19]$ some faults available in the region were categorized as active at the latest tectonic stage.

Relevance of this factor for the waste emplacement block can be estimated as high. Nevertheless, the risk of EBS deformations can be reduced significantly if the RW packages are disposed of outside the increased fracturing areas.

\section{FEP 1.2.4: Seismic activity}

Seismicity is associated with the tectonic movements constantly occurring in the earth's crust. The energy accumulated in the rocks along the faults is sometimes released in the form of earthquakes. Seismic events most commonly occur in tectonically active zones, usually along the boundaries of lithospheric plates. Although, intraplate seismicity belts are known as well. Seismic events most commonly manifest themselves on active faults.

Another mechanism triggering tectonic energy release is associated with human actions (induced seismicity), for example, by fluid injection into deep seated horizons. Induced earthquakes are usually relatively weak, can occur both in naturally seismically active areas and in areas characterized by low background seismicity.

In the long run, seismogenic processes triggering earthquakes can cause accidental damage to the engineered safety barrier system.

The Nizhnekanskiy rock mass region belongs to the periphery of an intraplate seismicity belt. Implemented studies showed that the lineament zones identified within the site and on its periphery cannot be considered as sources of seismic activity and are able of reflecting the waves coming from distant earthquakes. Estimated maximum intensity (MPE) of these seismic impacts amounted to 7.3 points according to the MSK-64 scale as referred to the medium soils. This means that seismic shakings of the underground repository structures will be even weaker and will have a limited impact on the repository safety. The total level of seismicity does not exceed the limits established by current regulations $[1,20,21]$.

However, in the long term, due to uncertainties in seismicity forecast for periods of more than 10 thousand years, the probability of very strong 
earthquakes resulting in some new tectonic displacements cannot be ruled out.

\section{FEP 1.2.8: Regional erosion}

(denudation) and sedimentation

Surface denudation (erosion) is a process associated with elevation. Sediment accumulation occurs at the adjoining territories experiencing immersion with the destroyed material deposited therein. Both processes can cause landscape transformations (related with FEP 1.2.13).

The intensity of denudation and the associated sedimentation in the neighboring depressions also depends on the climate (FEP 1.3) and the rock composition on the surface (FEP 4.1). Denudation of the surface in the repository siting region driven by another factor, for example, glacier advancement, seems to be unlikely [22].

Considering the proposed repository site located within a watershed area, available data on the elevation rates $[8,10,23]$ shows that significant erosion of the overlapping stratum can be practically excluded. Therefore, no significant accumulation of deposits (sedimentation) is expected in relevant depressions.

Additional studies of these processes are not required for scenario calculations.

\section{FEP 1.2.12: Hydrological and hydrogeological response to geological changes}

Large-scale geological movements (FEP 1.2.1) can affect the regional groundwater flow, also via groundwater pressure redistribution. Changes in hydrogeological setup caused by tectonic movements are usually followed by relevant changes in the rock - water system. Purpose studies are required to enable proper simulation of this process.

\section{FEP 1.2.13: Geomorphological response to geological changes}

Due to slight vertical differentiation of geological blocks in the repository siting region and subtle erosion and sedimentation processes, significant changes in the regional landscape are not expected. Nevertheless, changes in the surface elevations will affect the redistribution of water pressure in the underground horizons. The impact produced by landscape differentiation within the repository siting area on radionuclide migration was specified in a relevant forecast [12]. No additional studies are required for scenario calculations.

\section{FEP 1.2.14: Climatic responses to geological changes}

It is a common knowledge that over the past 15 million years, significant climate changes in the northern hemisphere were driven by the elevation of such mountain belts as the Alps, Tien Shan, Sayan Mountains and others located south of Europe and Siberia. It generally resulted in a drier climate and, particularly, the absence of glaciers in the southern regions of these territories during the last glaciation periods [24, 25]. Safety forecasts show that no significant mountain-building processes are expected. The climatic response to potential geological changes can be considered under purpose-developed regional models.

\section{Tasks for further research}

Initial stages of repository post-closure evolution feature short-term intensive processes resulting from engineering intrusion into natural medium: excavation of host rocks, emplacement of heat-generating HLW into the excavations and installation of engineered barriers, including, in particular, the development of excavation damaged zone (EDZ), drainage and subsequent resaturation of the host rocks and other processes occurring in the near field of the repository. These processes governing the short-term evolution of the repository mainly before its "closure" were deliberately excluded from consideration, since their evolution can be monitored, controlled or confidently predicted (for example, the response to host rock heating). In the long run, evolution mainly depends on the influence of external conditions, involving geological factors as was shown above.

Under the methodology suggesting that FEPs are used to plan research required for the long-term safety assessment of RW disposal system given a particular siting area, firstly, the relevance of particular FEPs for the given site should be specified, secondly, FEP impact (relevance) on repository evolution should be evaluated. Both procedures were discussed in the previous section.

Table 2 summarizes the data on geological FEPs that can affect the long-term disposal system evolution. If the FEP is specified as the one of low relevance, its study can be crossed out from the priority research list. Decisions enabling exclusion/ inclusion of particular processes being marked as of medium and high relevance are considered ambiguous and basically depend on the engineering and economic setup and the phase of the project, regulatory requirements and modeling maturity.

\section{Conclusions}

The following items are proposed to be included into the list of the most important research areas associated with geosphere FEPs: 


\section{Table 2. Selected features, events and processes associated with the geological environment of the Yeniseiskiy site and governing the evolution of the disposal system}

\begin{tabular}{|c|c|}
\hline $\begin{array}{c}\text { Impact produced on the } \\
\text { safety of the repository } \\
\text { to be constructed at the } \\
\text { Yeniseiskiy site }\end{array}$ & $\begin{array}{l}\text { Data uncertainties and tasks } \\
\text { for the top-priority research }\end{array}$ \\
\hline \multicolumn{2}{|c|}{ *1.2 Geological factors } \\
\hline \multicolumn{2}{|c|}{ 1.2.1 Tectonic movements } \\
\hline $\begin{array}{l}\text { Medium relevance for } \\
\text { vertical movements of } \\
\text { large blocks in the area }\end{array}$ & $\begin{array}{l}\text { There are no sound data on actual } \\
\text { amplitudes of modern horizontal } \\
\text { movements }\end{array}$ \\
\hline \multicolumn{2}{|c|}{ 1.2.3: Deformation (elastic, plastic or brittle) } \\
\hline $\begin{array}{l}\text { High relevance for the } \\
\text { disposal block }\end{array}$ & $\begin{array}{l}\text { No valid data on the availability, actual } \\
\text { location and current displacement } \\
\text { rates along the fracture zones inside } \\
\text { the disposal block }\end{array}$ \\
\hline \multicolumn{2}{|r|}{ 1.2.4: Seismicity } \\
\hline Limited impact & $\begin{array}{l}\text { Uncertainties in the seismicity forecast } \\
\text { covering a period of more than } \\
10 \text { thousand years. } \\
\text { The study of man-induced seismicity } \\
\text { resulting from the injection of liquid } \\
\text { radioactive waste and general seismic } \\
\text { monitoring }\end{array}$ \\
\hline \multicolumn{2}{|c|}{ 1.2.8: Regional erosion and sedimentation } \\
\hline Minimal impact & No additional research is required \\
\hline \multicolumn{2}{|c|}{$\begin{array}{c}\text { 1.2.12: Hydrological/hydrogeological response to geological } \\
\text { changes }\end{array}$} \\
\hline Minimal impact & $\begin{array}{l}\text { Specific studies are required to inves- } \\
\text { tigate the processes occurring within } \\
\text { "rock - water" system }\end{array}$ \\
\hline \multicolumn{2}{|c|}{ 1.2.13: Geomorphological response to geological changes } \\
\hline Medium relevance & No additional research is required \\
\hline \multicolumn{2}{|c|}{ 1.2.14: Climatic responses to geological changes } \\
\hline Minimal impact & Purpose-performed climatic forecast \\
\hline
\end{tabular}

* OECD NEA catalog's number

- study of tectonic movements, especially horizontal displacements along faults in the repository siting region;

- study of rock deformations, especially along zones of increased fracturing within the disposal block;

- seismic regional monitoring.

Studies associated with the indicated FEPs should be considered as top-priority ones; some of them are already being carried out or are planned to be implemented in the near future. Most studies will involve long-term observations.

\section{References}

1. Zahoronenie radioaktivnyh othodov. Principy, kriterii i osnovnye trebovaniya bezopasnosti. NP055-04 [Disposal of radioactive waste. Principles, criteria and main safety requirements. NP-055-04]. Yadernaya i radiacionnaya bezopasnost' - Nuclear and radiation safety, 2015, no. 4 (78), pp. 59-87.

2. IAEA Safety Glossary: Terminology Used in Nuclear Safety and Radiation Protection: 2016 Edition. Vienna: IAEA, 2016, 238 p.

3. Otchet o NIR po teme: «Geologicheskie raboty i predstavlyaemye dannye dlya ocenki bezopasnosti ob"ekta okonchatel'noj podzemnoj izolyacii RAO (v t.ch. podzemnoj laboratorii) na ploshchadke uchastka Enisejskij (Nizhnekanskij massiv) v procedure okonchatel'nogo utverzhdeniya ploshchadki» [R\&D report on Geological Exploration and Data Presented for the Safety Assessment of the Final Geological RW Disposal Facility (Including Underground Research Laboratory) at the Yeniseyskiy site (Nizhnekanskiy rock mass) under the Final Site Approval Procedure] / State Contract No. N.4d.21.04.09.1219 of June 11, 2009. M.: IGEM RAS, 2009.

4. Podgotovka materialov v ramkah razrabotki osnovnyh polozhenij po obosnovaniyu dolgovremennoj bezopasnosti PGZRO, sozdavaemogo na uchastke «Enisejskij» v Nizhnekanskom kristallicheskom massive. Tekhnicheskij otchet [Preparation of materials in the framework of development of basic guidelines for long-term safety case of DRWDF at «Yeniseysky» site in Nizhnekansk crystalline massif Technical Report]. Zharikov V. A., Kochkin B. T., Krupskaya V. V., Mal'kovskij V. I., Tarasov N. N., Yudincev S. V. Moscow, IGEM RAN, 2014.

5. Kochkin B. T. Princip konservatizma v ocenke bezopasnosti mogil'nikov vysokoradioaktivnyh othodov. [Conservatism Principle for the Safety Assessment of the High-Level Radioactive Waste Repository]. Geoekologiya. Inzhenernaya geologiya, gidrogeologiya, geokriologiya - Environmental Geoscience, 2012, no. 5, pp. 436-448.

6. Obosnovanie nomenklatury parametrov scenariev vozdejstviya prirodnyh i tekhnogennyh processov v usloviyah razmeshcheniya ob"ekta na Nizhnekanskom massive. Otchet o NIR (itogovyj): 08-08 [Rationale Behind the List of Parameters for Scenarios Associated with Natural and Technogenic Impacts under Conditions Relevant for the Facility Sited in the Nizhnekanskiy Rock Mass. R\&D Report (final) 08-08] / run by I. I. Linge. M., 2016. 136 p.

7. International Features, Events and Processes (IFEP) List for the Deep Geological Disposal of Radioactive Waste: Version 3.0 Radioactive Waste Management. NEA/RWM/R (2019) 1 July 2019 (www. oecd-nea.org). 
8. Issledovaniya granitoidov Nizhnekanskogo massiva dlya zahoroneniya RAO. Materialy KNTS. [Study of granitoids of Nizhnekansk range for RW disposal Materials of KNTS Zheleznogorsk, March 16-20, 1998]. St-Petersburg, MCC, SPA "Khlopin Radium Institute" publ., 1999. $182 \mathrm{p}$.

9. Anderson E. B., Belov S. V., Kamnev E. N., Kolesnikov I. Yu., Lobanov N. F., Morozov V. N., Tatarinov V. N. Podzemnaya izolyaciya radioaktivnyh othodov [Underground isolation of radioactive waste]. Moscow, Gornaya Kniga Publ., 2011. 592 p.

10. Kochkin B. T., Malkovskiy V. I., Yudintsev S. V. Nauchnye osnovy ocenki bezopasnosti geologicheskoj izolyacii dolgozhivushchih radioaktivnyh othodov (Enisejskij proekt) [Scientific basis for the safety assessment of long-lived radioactive waste geological disposal (the Eniseyskiy project)]. Moscow, IGEM RAS Publ., 2017. 384 p.

11. Tatarinov V. N., Kaftan V. I., Seelev I. N. Izuchenie sovremennoj geodinamiki Nizhnekanskogo massiva dlya bezopasnogo zahoroneniya radioaktivnyh othodov [Study of the Present-Day Geodynamics of the Nizhnekanskiy massif for Safe Disposal of Radioactive Wastes]. Atomnaya energiya - Atomic Energy, 2016, vol. 121, no. 3, pp. 157-160.

12. Kochkin B. T., Mal'kovskii V. I. Kolichestvennaya ocenka dolgosrochnoj evolyucii uslovij migracii radionuklidov iz mogil'nika na uchastke Enisejskij (Krasnoyarskij kraj) [Quantitative assessment of the longterm evolutionof radionuclide migration conditions from theunderground repository at the Yeniseiskii site (Krasnoyarsk region)]. Geoekologiya. Inzhenernaya geologiya, gidrogeologiya, geokriologiya - Environmental Geoscience, 2016, no. 5, pp. 401-411.

13. Lobackaya R. M. Neotektonicheskaya razlomnoblokovaya struktura zony sochleneniya Sibirskoj platformy i Zapadno-Sibirskoj plity [Neotectonic rupture-block structure of the conjunction zone of Siberian Platform and West Siberoan Plate]. Geologiya i geofizika - Geology and Geophysics, 2005, vol. 46, no. 12, pp. 141-150.

14. Morozov V. N., Tatarinov V. N., Kaftan V. I., Manevich A. I. Podzemnaya issledovatel'skaya laboratoriya: geodinamicheskie i sejsmotektonicheskie aspekty bezopasnosti [Underground Research Laboratory: Geodynamic and Seismottectical Aspects of Safety]. Radioaktivnye othody - Radioactive Waste, 2018, no. 3 (4), pp. 16-29.

15. Tatarinov V. N., Morozov V. N., Kaftan V. I., Manevith A. I., Tatarinova T. A. Podzemnaya issledovatel'skaya laboratoriya: zadachi geodinamicheskih issledovanij [Underground research laboratory: problems of geodynamic research]. Radioaktivnye othody-Radioactive Waste, 2019, no.1(6), pp. 77-89. 16. Nikolaev N. I. Novejshaya tektonika i geodinamika litosfery [Latest tectonics and geodynamics of the lithosphere]. Moscow, Nedra Publ., 1988. 491 p.
17. Nikonov A. A. Terminologiya i klassifikaciya sejsmogennyh narushenij rel'efa [Terminology and classification of seismogenic violations of the terrain]. Geomorfologiya-Geomorphology, 1995, no. 1, pp. $4-10$.

18. Lukina N. V. Aktivnye razlomy zony sochleneniya Sibirskoj platformy i Altae-Sayanskoj orogenicheskoj oblasti [Active ruptures of the conjunction zone of the Siberian Platform and Altay-Sayany orogenic area]. Byulleten' moskovskogo obshchestva ispytatelej prirody. Otd. Geologicheskoe - Bulletin of the Moscow society of naturalists. Geological section, 1996, vol. 71, no. 5, pp. 25-32.

19. Nesmeyanov S. A., Voejkova O. A. Aktivnye razryvy $\mathrm{v}$ zone sochleneniya yuga Sibirskoj platform i Zapadno-Sibirskoj plity i ih znachimost' dlya stroitel'stva [Active ruptures in the conjunction zone of the south of Siberian Platform and West Siberian Plate and their importance for construction]. Geoekologiya. Inzhenernaya geologiya, gidrogeologiya, geokriologiya - Environmental Geoscience, 2008, no. 3, pp. 197-213.

20. Federal'nye normy i pravila v oblasti ispol'zovaniya atomnoj energii. Uchet vneshnih vozdejstvij prirodnogo i tekhnogennogo proiskhozhdeniya na ob"ekty ispol'zovaniya atomnoj energii. NP-064-17. [Federal norms and rules in the field of atomic energy use. Accounting for external impacts of natural and man-made origin produced on nuclear facilities. NP-064-17].

21. Rukovodstvo po bezopasnosti. Ocenka sejsmicheskoj opasnosti uchastkov razmeshcheniya yaderno- i radiacionno opasnyh ob"ektov na osnovanii geodinamicheskih dannyh. RB-019-01. [Safety guide. Seismic Hazard Assessment for Sites with Nuclear and Radiation Hazardous Facilities Based on Geodynamic Data. RB-019-01]. Vestnik Gosatomnadzora Rossii - Bulletin of the Gosatomnadzor of Russia, 2002, no. 1, pp. 33-39.

22. Kochkin B. T. Dolgosrochnyj prognoz klimaticheskih izmenenij $\mathrm{v}$ rajone razmeshcheniya hranilishcha vysokoradioaktivnyh othodov (uchastok Enisejskij, Krasnoyarskij kraj) [Long-term forecast of climate changes in the location area of repository for high-level radioactive wastes (Yeniseysky site, the Krasnoyarsk region)]. Geoekologiya. Inzhenernaya geologiya, gidrogeologiya, geokriologiya - Environmental Geoscience, 2015, no. 2, pp. 52-65.

23. Anderson E. B., Savonenkov V. G., Lyubceva E. F. i dr. Rezul'taty poiskovyh i nauchno-issledovatel'skih rabot po vyboru ploshchadok dlya podzemnoj izolyacii VAO i OYAT na Nizhnekanskom massive granitoidov (Yuzhno-Enisejskij kryazh) [The results of prospecting and scientific works on site selection to geological disposal of HLW and SNF in the Nizhnekanskiy granitoid massif (South Yenisei Ridge)]. Trudy 
Radievogo instituta im. V. G. Hlopina, 2006, vol. XI, pp. 8-64.

24. Velichko A. A. Stanovlenie sovremennoj landshaftnoj obolochki Zemli [Formation of the Earth's Modern Landscape Mantle]. Priroda - Nature, 2012, no. 1 , pp. $78-87$.
25. Izmenenie klimata $i$ landshaftov za poslednie 65 millionov let (Kajnozoj: ot paleocena do golocena) [Climate and environment changes during the last 65 million years (Cenozoic: from paleocene to holocene)]. Ed. A. A. Velichko. Moscow, GEOS Publ., 1999. $260 \mathrm{p}$.

\section{Information about the authors}

Kochkin Boris Timofeevich, Doctor of Science, Principal scientist, Institute of Geology of Ore Deposits, Petrography, Mineralogy, and Geochemistry of the Russian Academy of Sciences (35, Staromonetnyi Lane, Moscow, 119017, Russia), Senior scientist, Nuclear Safety Institute of the Russian Academy of Sciences (52, Bolshaya Tulskaya St., Moscow, 115191, Russia), e-mail: btk@igem ru.

Bogatov Sergey Aleksandrovich, PhD, Senior Researcher, Nuclear Safety Institute of the Russian Academy of Sciences (52, Bolshaya Tulskaya St., Moscow, 115191, Russia), e-mail: sbg@ibrae.ac.ru.

Barinov Aleksandr Sergeevich, PhD, Senior Researcher, Nuclear Safety Institute of the Russian Academy of Sciences (52, Bolshaya Tulskaya St., Moscow, 115191, Russia), e-mail: barinov@ibrae ac ru.

Saveleva Elena Aleksandrovna, PhD, Head of laboratory, Nuclear Safety Institute of the Russian Academy of Sciences (52, Bolshaya Tulskaya St., Moscow, 115191, Russia), e-mail: esav@ibrae ac.ru.

Utkin Sergey Sergeevich, Doctor of Technical Sciences, Head of Department, Nuclear Safety Institute of the Russian Academy of Sciences (52, Bolshaya Tulskaya St., Moscow, 115191, Russia), e-mail: uss@ibrae.ac.ru.

\section{Bibliographic description}

Kochkin B. T., Bogatov S. A., Barinov A. S., Saveleva E. A., Utkin S. S. Evolution of geosphere at the site in Nizhnekanskiy massif meant for deep geological disposal. Radioactive Waste, 2020, no. 1 (10), pp. 56-65. (In Russian). DOI:10.25283/2587-9707-2020-1-56-65. 